DOI: https://doi.org/10.47405/mjssh.v6i3.716

\begin{tabular}{|c|c|}
\hline 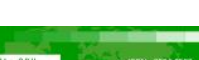 & Malaysian Journal of Social Sciences and Humanities (MJSSH) \\
\hline Malaysian Journal of & Volume 6, Issue 3, March 2021 \\
\hline (MJ-ssH) & e-ISSN : 2504-8562 \\
\hline & $\begin{array}{l}\text { Journal home page: } \\
\text { www.msocialsciences.com }\end{array}$ \\
\hline
\end{tabular}

\title{
Hubungan Antara Efikasi Kendiri dan Motivasi Terhadap Pencapaian Akademik Pelajar Perempuan Jurusan STEM
}

\author{
Zulyna Adila Zainuddin'1, Faridah Mydin Kutty ${ }^{1}$ \\ ${ }^{1}$ Fakulti Pendidikan, Universiti Kebangsaan Malaysia (UKM) \\ Correspondence: Zulyna Adila Zainuddin (p101143@siswa.ukm.edu.my)
}

\begin{abstract}
Abstrak
Efikasi kendiri dan motivasi berperanan penting dalam menyumbang kepada pencapaian akademik pelajar. Tujuan kajian ini adalah untuk melihat kepada tahap efikasi kendiri dan tahap motivasi pelajar perempuan jurusan STEM berdasarkan kepada pencapaian akademik yang diperolehi daripada semester lepas. Kajian ini menggunakan kaedah kuantitatif. Sejumlah 306 pelajar perempuan daripada jurusan STEM menjawab soal selidik dengan menggunakan kaedah google form. Hasil kajian di analisis secara deskriptif dan inferensi dengan menggunakan Statistical Package for Social Science (SPSS) versi 25.0. Hasil dapatan menunjukkan korelasi positif $(r=0.614)$ antara efikasi kendiri dan motivasi pelajar. Ini menunjukkan bahawa tahap efikasi kendiri yang tinggi juga dipengaruhi oleh tahap motivasi pelajar yang tinggi. Namun demikian, hubungan yang diperolehi antara antara efikasi kendiri dan CGPA pelajar adalah $(r=0.103)$, manakala bagi motivasi dan CGPA pelajar adalah $(r=$ 0.042). Kesimpulannya, terdapat hubungan sangat lemah di antara efikasi kendiri dan motivasi terhadap pencapaian akademik pelajar. Ini kerana hasil dapatan menujukkan bahawa tahap efikasi kendiri dan tahap motivasi pelajar turut mempengaruhi pencapaian akademik pelajar perempuan jurusan STEM walaupun hubungan yang diperolehi adalah hubungan sangat lemah.
\end{abstract}

Kata kunci: efikasi kendiri, motivasi, STEM, pembelajaran STEM, pelajar perempuan STEM

\section{The Relationship Between Self-Efficacy and Motivation Towards Academic Performance of Female Students in STEM}

\begin{abstract}
Self-efficacy and motivation are one of the main factors that can contribute to students' academic performance. This study aimed to assess the level of self-efficacy and motivation of female students in STEM through their current academic performance from the last semester. This study used a quantitative method where a total of 306 female students in STEM were selected to answer the questionnaire given by using google form. The results of the study were analyzed using descriptive and inferential statistics by using the Statistical Package for Social Science (SPSS) version 25.0. The findings showed a positive correlation $(r=0.614)$ between self-efficacy and motivation which can be defined as that if students have high self-efficacy it can affect student motivation as well. However, the relationship between self-efficacy $(r=0.103)$ and motivation $(r=0.042)$ towards student females in STEM showed the relationship is very weak. It can be concluded that self-efficacy and motivation have affected student's academic performance of female students in STEM.
\end{abstract}

Keywords: self- efficacy, motivation, STEM, STEM education, women in STEM 


\section{Pengenalan}

Pendidikan Sains, Teknologi, Kejuruteraan dan Matematik ialah pendidikan yang bertunjangkan pengintegrasian empat bidang yang dikenali sebagai STEM. Dalam konteks Malaysia, Pendidikan STEM ini merupakan salah satu agenda yang ditekankan dalam pelaksanaan Pelan Pembangunan Pendidikan Malaysia (PPPM) 2013-2025. Dasar dan agenda utama adalah merujuk kepada sasaran utama KPM untuk menambah nisbah pelajar dalam jurusan STEM. Dalam usaha untuk menambah nisbah pelajar, minat dan kebolehan seseorang pelajar diperlukan dalam jurusan yang dipilih. Ini kerana melalui minat dan kebolehan tersebut ia dapat memastikan pelajar untuk sentiasa bersungguhsungguh.

Muhammad Abd (2017) menyatakan secara jelas dalam dokumen Pelan Transformasi Ekonomi yang mahukan warganegara Malaysia mengungguli sains dan kejuruteraan melalui penciptaan. Untuk memastikan jurusan kejuruteraan menjadi pilihan utama pelajar perempuan jurusan STEM, setiap faktor yang mampu menyumbang kepada pencapaian akademik pelajar dalam jurusan yang dipilih ini perlu diambil kira. Melalui kenyataan yang diberikan, ini dapat dikaitkan dengan pelajar perempuan jurusan STEM di Malaysia. Ini kerana, hampir sebahagian daripada pelajar jurusan STEM adalah dimonopoli oleh pelajar perempuan pada masa kini, terutamanya dalam jurusan Sains seperti kejururawatan (Khuzaimah \& Siti Salina, 2019). Disebabkan kurangnya konteks kajian terhadap pendidikan STEM di negara ini, kajian ini ingin melihat kepada tahap efikasi kendiri pelajar dan tahap motivasi terhadap pencapaian akademik pelajar perempuan jurusan STEM.

Antara kajian yang dilakukan di negara ini berkaitan dengan pendidikan STEM adalah kajian Amimah (2018) yang menyatakan masih terhad dan kabur kesedaran mengenai pendidikan STEM di Malaysia. Kajian Nur Amelia dan Lilia (2019) pula lebih tertumpu kepada cabaran dalam mengintegrasikan pendidikan STEM dalam kurikulum Malaysia. Bagi kajian di negara luar pendidikan STEM pula lebih tertumpu kepada penindasan jantina secara amnya. Contoh kajian yang dijalankan oleh Sabrina dan Nicole (2019) meneliti kesan penindasan jantina kepada pelajar STEM. Antara kajian lain, adalah kajian Rebecca dan Fani (2019) yang masih lagi memfokuskan jantina sebagai isu utama tetapi meilihat kepada pendekatan motivasi beserta pilihan karier pelajar STEM tersebut. Jurusan STEM yang dulu dimonopoli oleh pelajar lelaki kini mula diminati oleh pelajar perempuan, adalah kenyataan daripada pengkaji Alexandra dan Wendi (2018) yang mengatakan pelajar perempuan dalam jurusan ini juga pada awalnya mempunyai perasaan bimbang yang meninggi kerana mereka beranggapan jurusan STEM ini sukar untuk dilakukan disebabkan sifat dan identiti yang berbeza dengan pelajar lelaki. Anne, Elsbeth dan Renate (2019) menyatakan pelajar perempuan dalam jurusan ini akan menghadapi kesukaran sama ada ingin terus memilih bidang STEM di peringkat yang lebih tinggi atau sebaliknya.

Tambahan pula, kurangnya konteks di Malaysia yang melihat kepada jantina, menyebabkan kajian ini dilakukan secara lebih terbuka terhadap perihal jantina terhadap jurusan STEM di negara ini. Susan et al. (2019), menyatakan motivasi dan efikasi kendiri pelajar telah dikenal pasti sebagai penyumbang utama kejayaan pelajar di peringkat pengajian tinggi dalam menentukan pelajar untuk terus kekal dalam jurusan yang dipilih serta mempengaruhi kejayaan yang bakal mereka perolehi. Memilih bidang yang bersesuaian dengan minat seseorang pelajar mampu menjadikan dorongan yang positif dalam menghasilkan pelajar yang bermotivasi. Melalui kajian ini juga terdapat beberapa implikasi yang akan mendatangkan kesan kepada bidang pendidikan terutamanya dalam bidang STEM. Di mana, terdapatnya perkaitan di antara pelajar perempuan jurusan STEM terhadap pencapaian akademik yang akan mendatangkan kesan terhadap pemboleh ubah yang ingin dikaji oleh pengkaji. Untuk mengetahui keupaayan pemboleh ubah, kajian ini perlu dilakukan agar dapatan yang diberikan mampu memberikan impak kepada tahap motivasi dan tahap efikasi kendiri pelajar yang terlibat dalam kajian ini.

Oleh itu, kajian ini penting untuk dijalankan kerana pendidikan STEM tidak meluas serta tidak melihat kepada pelajar perempuan semata- mata dalam konteks di Malaysia. Kurangnya konteks kajian di peringkat tinggi dalam pendidikan STEM di Malaysia menjadikan kajian ini perlu dilakukan serta 
dikupas di peringkat pengajian tinggi dengan lebih mendalam. Hal ini kerana, Wondu Teshome Beharu (2018) menyatakan motivasi juga merupakan titik permulaan bagi pelajar dalam usaha untuk mengekalkan momentum serta mempunyai minat berterusan dalam menghabiskan jurusan yang di pilih sehingga ke akhir pembelajaran. Soleiman Ahmady et al. (2019) mengemukakan terdapat hubungan yang positif di antara efikasi kendiri dan pencapaian akademik pelajar. Keupayaan efikasi kendiri pelajar dalam memenuhi sesuatu tuntutan tentang apa yang dipelajari juga memainkan peranan penting. Ini kerana efikasi kendiri yang dimiliki pelajar mampu membawa kepada perubahan yang lebih baik atau sebaliknya.

Dengan mengenal pasti keupayaan pencapaian pelajar perempuan terhadap jurusan STEM melalui pemboleh ubah efikasi kendiri dan motivasi, kajian ini haruslah dijalankan untuk memastikan ketiga tiga objektif yang ingin dilihat tercapai iaitu :

1. Mengenal pasti tahap efikasi kendiri pelajar perempuan jurusan STEM di universiti awam.

2. Mengenal pasti tahap motivasi pelajar perempuan jurusan STEM di universiti awam.

3. Mengenal pasti hubungan di antara efikasi kendiri dan motivasi pelajar perempuan jurusan STEM di universiti awam dengan pencapaian akademik.

\section{Sorotan Literatur}

Menurut Pelan Pembangunan Pendidikan Malaysia 2013- 2025, pelan tindakan telah menghasilkan tiga gelombang yang berkaitan dengan pendidikan STEM. Antaranya adalah memerihalkan pengukuhan ke atas pembelajaran, membina asas yang disediakan dan melakukan inovasi pada peringkat seterusnya. Begitu juga dengan pendidikan STEM di negara ini, beberapa inisiatif dilakukan oleh Kementerian Pendidikan Malaysia (KPM) yang berusaha untuk meningkatkan sumber tenaga yang mahir serta pakar dalam bidang penyelidikan dan industri. Kenyataan yang diberikan oleh KPM dapat diselarikan dengan kajian ini yang ingin menempatkan pendidikan STEM sebagai fokus utama kajian yang ingin melihat kepada penyertaan pelajar perempuan jurusan STEM terhadap pencapaian akademik mereka.

Penyertaan pelajar perempuan dalam STEM di IPT pada masa kini agak memuaskan jika hendak dibandingkan denagan sikap ketidakterbukaan tentang STEM sebelum ini. Kenyataan Lizhi He et al. (2020) menyatakan pelajar perempuan jurusan STEM telah mencapai pencapaian yang memberangsangkan dalam beberapa dekad kebelakangan ini, terutama di peringkat pengajian tinggi. Menurut Kumar Jha C. dan Sarangi, S.(2018) peningkatan penyertaan pelajar perempuan dalam jurusan STEM dan jurusan lain mampu memberikan kesan yang positif kepada pertumbuhan ekonomi secara keseluruhan sewaktu menempuhi sektor pekerjaan kelak. Yasmeen Makarem dan Jia Wang (2019) mentakrifkan pelajar perempuan yang memilih jurusan STEM merupakan seorang wanita yang mempunyai daya saing yang tinggi, ini kerana sikap kepemimpinan yang diperolehi oleh mereka.

Pencapaian akademik pelajar dapat diukur mengikut tahap yang diperolehi oleh pelajar. Tahap yang dimaksudkan terbahagi kepada dua. Tahap yang lebih tinggi diukur dengan melihat kepada pencapaian akademik pelajar yang memperolehi nilai yang tinggi dan begitu pula sebaliknya bagi pelajar yang memperolehi nilai yang lebih rendah. Menurut Ching-Hsue, Yun-Chun dan Wei-Xiang (2019) konsep pencapaian akademik pelajar boleh di nilai melalui keputusan yang diperolehi mengikut tahap yang lebih rendah dan juga tahap yang lebih tinggi. Oleh itu, pencapaian akademik yang dimaksudkan dalam kajian ini adalah dengan melihat tahap keputusan yang dimiliki oleh pelajar.

Melalui pencapaian akademik yang mengikut tahap sama rata adalah dengan dapatan gred yang diperolehi oleh pelajar. Di mana bagi pelajar perempuan jurusan STEM di peringkat pengajian tinggi, pencapaian akademik mereka boleh diukur dengan nilai CGPA yang diperolehi sepanjang semester dijalankan. Nilai CGPA yang diperolehi bukan hanya menyumbang kepada pencapaian akademik pelajar STEM semata, malahan hampir kepada keseluruhan pelajar di peringkat pengajian tinggi memperolehi nilai dalam bentuk CGPA dan GPA yang sama. Ini selari dengan kajian Muhammad Dzharil Shah Andarin dan Noor Raudhiah Abu Bakar (2017) pencapaian akademik yang dimaksudkan datangnya daripada gred yang diperolehi oleh pelajar setelah mereka menduduki peperiksaan. 
Sekiranya seseorang pelajar itu memperolehi gred yang baik maka dapat disimpulkan bahawa pencapaian akademik yang diperolehi adalah memberangsangkan.

Ditakrifkan oleh Sabrina et al. (2019) bagi pelajar STEM hasil prestasi akademik dalam jangka masa panjang yang positif dapat diterjemahkan kepada nilai tinggi yang bakal diperolehi pada tahun kedua kuliah atau melihat kepada kegigihan utama pelajar. Oleh itu, untuk mengekalkan momentum prestasi yang cemerlang sepanjang masa, pelajar STEM harus sentiasa mempunyai kegigihan untuk terus berjaya. Pengukuran terhadap pencapaian akademik pelajar perempuan STEM yang dijalankan dalam kajian ini adalah untuk melihat kepada tahap efikasi kendiri dan tahap motivasi pelajar yang mampu memberi impak kepada pencapaian akademik pelajar perempuan jurusan STEM.

Teori kognitif sosial yang dipelopori oleh Bandura (1986) menerangkan bahawa kepercayaan individu adalah berkaitan dengan efikasi kendiri seseorang yang membolehkannya melaksanakan sesuatu tugas tertentu secara langsung yang akhirnya mampu mendorong individu dalam sesuatu bidang yang diceburi. Melalui teori ini juga, tingkah laku seseorang individu dapat dibentuk berdasarkan kepada proses pemikiran dan refleksi keseluruhan. Ini dapat dibentuk dengan cara individu membuat perancangan awal secara sistematik berdasakan apa yang ingin dicapai dari segi aktiviti harian mereka. Dalam perspektif kognitif sosial, individu dipandang sebagai seorang yang berkemampuan untuk mengatur diri daripada dikawal oleh kekuatan biologis atau persekitaran. Teori kognitif sosial menganggap bahawa efikasi kendiri merupakan kunci utama dalam mempengaruhi cara individu belajar. Pelajar yang mempunyai tahap efikasi kendiri yang tinggi juga mempunyai kualiti belajar yang lebih baik dan memiliki sifat kawalan diri yang baik dalam menghasilkan pencapaian akademik yang lebih baik berbanding dengan pelajar yang mempunyai tahap efikasi yang rendah. Hasil positif terhadap pembelajaran dengan tahap efikasi kendiri yang mendorong kepada pencapaian akademik yang baik adalah disebabkan ketekunanan, pilihan serta minat pelajar dan cara pembelajaran yang efektif .

Menurut Sarah, Karyn dan Tiffany (2019) pelajar yang mempunyai efikasi kendiri yang tinggi mempercayai bahawa mereka mempunyai kemampuan intelektual yang lebih rendah berbanding dengan rakan yang lain. Ini kerana seseorang pelajar yang mempunyai kecekapan diri yang rendah akan mempersoalkan kemampuannya untuk mendapatkan prestasi yang baik dalam melakukan tugasan dan peperiksaan yang dihadapi dan masih mempercayai bahawa mereka masih setanding dengan rakan yang lain. Kajian Cameron dan Jay Stratte (2017) menyatakan kesesuaian dan penglibatan efikasi kendiri individu mendorong kepada hampir semua aspek pertumbuhan dalam mengenal pasti peningkatan kepada pencapaian akademik pelajar. Hal ini adalah bersesuaian dengan hubungan di antara pelajar STEM yang dibina untuk mengenal pasti kecekapan diri sebagai aspek utama dalam meningkatkan pencapaian akademik pelajar. Oleh yang demikian, kemampuan intelektual dan penglibatan pelajar dapat memberikan impak kepada efikasi kendiri pelajar terhadap pencapaian akademik mereka.

Motivasi juga bertindak sebagai agen yang mempengaruhi pencapaian akademik pelajar sebelum dipengaruhi oleh tingkah laku pelajar terhadap jurusan yang dipilih (Susana et al., 2019). Bagi pelajar jurusan STEM, faktor dalaman adalah faktor utama kurangnya motivasi, ini kerana kurangnya motivasi boleh menyebabkan penglibatan pelajar berkurang dalam bidang akademik. Salah satu masalah yang menyebabkan pelajar tidak terdorong untuk belajar dalam jurusan ini adalah disebabkan kurangnya penggunaan pelajaran teori dalam latihan praktikal dan klinikal (Mohammad Reza et al, 2018). Sultan (2019) mengemukakan motivasi yang terdapat pada pelajar adalah disebabkan efikasi kendiri pelajar berkenaan yang mampu membawa kepada kawalan kendiri yang lebih baik berdasarkan nilai pembelajaran yang dimiliki oleh pelajar dalam mendapatkan keputusan akademik yang lebih baik di kalangna pelajar yang terlibat. Oleh yang berikut efikasi kendiri mampu mempengaruhi motivasi pelajar dalam menghasilkan akademik pelajar yang cemerlang.

Pelajar yang memiliki keputusan yang baik dapat memenuhi dalaman dan luaran sesuatu keadaan yang menyebabkan tugasan yang diberikan dapat dilaksanakan, seterusnya memenuhi penglibatan pelajar secara menyeluruh yang akhirnya membawa kepada pencapaian akademik pelajar yang lebih cemerlang (Susana et al., 2019). Oleh yang demikian, pencapaian akademik pelajar STEM adalah 
disebabkan atas faktor yang dimiliki oleh individu terhadap tugasan yang dapat dilakukan, peglibatan pelajar tersendiri yang mampu mengekalkan prestasi dan pencapaian akademik pelajar. Disebabkan kurangnya konteks kajian di negara ini, pengkaji perlu melihat kepada pelajar perempuan jurusan STEM yang menjadi minoriti dalam jurusan STEM ini. Ini kerana kesan dan pencapaian akademik pelajar mampu membawa kepada perubahan dan titik permulaan kepada seseorang individu. Meningkatnya pencapaian akademik mampu membawa ke arah dapatan yang lebih baik dan ke peringkat yang lebih tinggi untuk terus berada dalam sesuatu jurusan.

\section{Metod Kajian}

Reka bentuk kajian adalah kuantitatif yang menggunakan pendekatan kaedah persampelan bertujuan. Terdapat dua jenis statistik yang berbeza untuk menganalisis data dalam kajian, iaitu statistik deskriptif dan statistik inferensi. Statistik deskriptif digunakan untuk melihat kepada kekerapan dan peratus terhadap maklumat demografi responden beserta tahap efikasi kendiri dan tahap motivasi pelajar. Bagi statistik inferensi pula korelasi Spearmen digunakan. Ini kerana data yang diperolehi adalah untuk melihat hubungan di antara efikasi kendiri dan tahap motivasi terhadap pelajar perempuan jurusan STEM dengan pencapaian akademik yang berbentuk ordinal dan bersifat bukan parametrik. Kajian ini juga melibatkan seramai 306 orang responden merujuk kepada jadual Krejcie dan Morgan (1970) yang responden nya terdiri daripada pelajar perempuan jurusan STEM.

Soal selidik yang diberikan kepada responden adalah secara atas talian dengan menggunakan kaedah google form. Penggunaan soal selidik yang digunakan adalah berbentuk tertutup dan terbuka. Melalui instrumen soal selidik ini, ia dibangunkan dengan melihat kepada pemboleh ubah yang ingin dikaji beserta pemilihan soalan yang bersesuaian. Bagi instrumen efikasi kendiri pengkaji merujuk sumber General Self-Efficacy Scale (GSE) manakala untuk melihat kepada tahap motivasi pelajar, pengkaji merujuk dan menggunakan instrumen 'Motivated Strategies for Learning Questionnaire (MSLQ)'. Soal selidik yang digunakan mempunyai tiga bahagian iaitu bahagian A adalah berkaitan dengan demografi responden dengan sebanyak 4 soalan. Bagi bahagian $\mathrm{B}$, berkaitan dengan tahap efikasi kendiri pelajar dengan sebanyak 16 soalan dan bahagian $\mathrm{C}$ soal selidik adalah berkaitan dengan tahap motivasi pelajar yang mengandungi 16 soalan. Melalui soal selidik ini juga kajian ini digunakan untuk mengenal pasti tahap yang dimiliki oleh pelajar perempuan jurusan STEM terhadap kedua pemboleh ubah yang ingin dikaji iaitu tahap efikasi kendiri dan tahap motivasi pelajar perempuan jurusan STEM.

Pengkaji menjalankan kajian rintis dengan mengedarkan soal selidik kepada 30 orang responden perempuan jurusan STEM untuk mengetahui soalan yang diberikan adalah mudah difahami atau sebaliknya. Sebelum soal selidik diedarkan untuk kajian rintis yang sebenar, tiga orang pakar telah di pilih untuk memberikan kesahan kandungan terhadap soal selidik yang akan digunakan. Pakar- pakar tersebut terdiri daripada pensyarah kanan daripada Fakulti Pendidikan (UKM), Fakulti Pengajian Pendidikan (UPM) dan juga guru kanan matapelajaran bahasa (SMK Puteri). Pemilihan pakar adalah berdasarkan kepada bidang kepakaran mereka. Dapatan daripada kajian rintis terhadap item efikasi kendiri, nilai pekali alfa yang diperolehi adalah sebanyak 0.946 dan bagi nilai pekali alfa pada item motivasi adalah sebanyak 0.809 .

Data yang diperolehi dalam kajian ini dianalisis dengan menggunakan SPSS versi 25.0. Data yang diperolehi dihuraikan secara terperinci menerusi kaedah penjadualan dalam hasil kajian. Melalui dapatan soal selidik responden, instrumen tersebut memerlukan penganalisisan data dengan lebih terperinci. Bagi demografi responden, data yang diperolehi diberikan penerangan yang sistematik mengenai ciri-ciri sesuatu populasi secara fakta dan tepat. Melalui penggunaan analisis deskriptif ini juga dapat diberikan penerangan yang lebih mendalam terhadap min dan sisihan piawai yang diperolehi oleh pengkaji terhadap tahap pemboleh ubah yang ingin dikaji oleh pengkaji. Korelasi Spearmen digunakan untuk menguji hubungan di antara efikasi kendiri dan tahap motivasi pelajar perempuan jurusan STEM dengan pencapaian akademik. Sekiranya terdapat hubungan yang positif dan signifikan antara tahap motivasi dan efikasi kendiri dengan pencapaian akademik, ini menunjukkan pembolehubah tersebut dikenali sebagai petunjuk sejauh mana kekuatan sesuatu pemboleh ubah dengan pemboleh ubah yang lain. 


\section{Hasil Kajian}

\section{Demografi Responden}

Jadual 1 menunjukkan dapatan data demografi responden berkaitan dengan umur, kaum, jurusan pendidikan STEM dan GPA semester lepas pelajar. Dapatannya dapat dirumuskan dengan merujuk kepada jadual di bawah.

Jadua1: Demografi Responden (N=306)

\begin{tabular}{cccc}
\hline & Maklumat Demografi & Frekuensi & Peratus (\%) \\
\hline Umur & 18 tahun- 25 tahun & 282 & 92.2 \\
& 26 tahun- 39 tahun & 24 & 7.8 \\
Kaum & Melayu & 291 & \\
& Cina & 8 & 95.1 \\
& India & 3 & 2.6 \\
& Lain-lain & 4 & 1.0 \\
& & & 1.3 \\
Jurusan & Sains & 201 & 65.7 \\
Pendidikan & Teknologi & 27 & 8.8 \\
STEM & Engineering (Kejuruteraan) & 48 & 15.7 \\
& Matematik & 30 & 9.8 \\
CGPA & & & \\
Semester & $4.00-3.68$ & 135 & 44.2 \\
Lepas & $3.67-3.34$ & 85 & 27.8 \\
& $3.33-3.01$ & 47 & 15.3 \\
& $3.00-2.68$ & 30 & 9.8 \\
& $2.67-2.34$ & 8 & 2.6 \\
& $2.33-2.01$ & 1 & 0.3 \\
\hline
\end{tabular}

\section{Tahap Efikasi Kendiri Pelajar Perempuan Jurusan STEM}

Dalam bahagian ini, Jadual 2 menunjukkan analisis deskriptif terhadap nilai min keseluruhan bagi tahap efikasi kendiri pelajar perempuan jurusan STEM adalah tinggi $(\mathrm{M}=3.92$, SP=0.604). Hal ini menunjukkan tahap efikasi kendiri yang dimiliki dalam kalangan pelajar perempuan jurusan STEM adalah tinggi.

Jadual 3: Nilai Min bagi Item Efikasi Kendiri

\begin{tabular}{|c|c|c|c|}
\hline Item & Bilangan Item & Nilai Min & Sisihan Piawai \\
\hline Efikasi Kendiri & 16 & 3.92 & 0.604 \\
\hline
\end{tabular}

\section{Tahap Motivasi Pelajar Perempuan Jurusan STEM}

Dalam bahagian ini, Jadual 3 menunjukkan analisis deskriptif terhadap nilai min keseluruhan bagi tahap motivasi pelajar perempuan jurusan STEM adalah tinggi $(\mathrm{M}=3.93, \mathrm{SP}=0.504)$. Hal ini menunjukkan tahap efikasi kendiri yang dimiliki dalam kalangan pelajar perempuan jurusan STEM adalah tinggi.

Jadual 3: Nilai Min bagi Item Motivasi

\begin{tabular}{|c|c|c|c|}
\hline Item & Bilangan Item & Nilai Min & Sisihan Piawai \\
\hline Motivasi & 16 & 3.93 & 0.504 \\
\hline
\end{tabular}




\section{Hubungan di antara efikasi kendiri dan motivasi pelajar perempuan jurusan STEM dengan pencapaian akademik}

Dapatan terhadap analisis korelasi Spearmen adalah seperti dalam jadual 4 yang berikut. Hasil analisis menujukkan, terdapat hubungan yang kuat dengan nilai $r=0.614$ antara efikasi kendiri dan motivasi pelajar perempuan jurusan STEM. Bagi efikasi kendiri dan CGPA semester lepas terdapat hubungan yang sangat lemah iaitu $r=0.103$, begitu juga dengan hubungan antara motivasi dengan CGPA semester lepas pelajar dengan nilai $r=0.042$. Ini bermakna tahap efikasi kendiri dan tahap motivasi mempunyai perkaitan yang positif iaitu kuat. Tahap tinggi yang diperolehi menunjukkan semakin tinggi tahap efikasi kendiri, semakin tinggi juga tahap motivasi pelajar. Melihat kepada tahap efikasi kendiri dan tahap motivasi yang dimiliki oleh pelajar, ini menunjukkan terdapat hubungan yang mempengaruhi pencapaian akademik pelajar perempuan jurusan STEM.

Jadual 4: Hubungan tahap efikasi kendiri dan tahap motivasi pelajar perempuan jurusan STEM dengan pencapaian akademik

\begin{tabular}{|c|c|c|c|c|c|}
\hline & & & CGPA & $\begin{array}{l}\text { Efikasi } \\
\text { Kendiri }\end{array}$ & Motivasi \\
\hline \multirow{10}{*}{$\begin{array}{l}\text { Spearmen's } \\
\text { Rho }\end{array}$} & \multirow[t]{4}{*}{ CGPA } & Correlation & 1.000 & .103 & .042 \\
\hline & & Coefficient & & .072 & .467 \\
\hline & & Sig. (2-tailed) & 306 & 306 & 306 \\
\hline & & $\mathrm{N}$ & & & \\
\hline & \multirow{3}{*}{$\begin{array}{l}\text { Efikasi } \\
\text { Kendiri }\end{array}$} & Correlation & .103 & 1.000 & $.614^{* *}$ \\
\hline & & Coefficient & .072 & & .000 \\
\hline & & $\begin{array}{c}\text { Sig. (2-tailed) } \\
\mathrm{N}\end{array}$ & 306 & 306 & 306 \\
\hline & \multirow[t]{3}{*}{ Motivasi } & Correlation & .042 & $.614^{* *}$ & 1.000 \\
\hline & & Coefficient & .467 & .000 & \\
\hline & & Sig. (2-tailed) & 306 & 306 & 306 \\
\hline
\end{tabular}

**. Correlation is significant at the 0.01 level (2-tailed).

\section{Perbincangan Kajian}

Tujuan kajian ini dijalankan adalah untuk melihat kepada tahap efikasi kendiri dan tahap motivasi pelajar perempuan jurusan STEM terhadap pencapaian akademik yang diperolehi. Melalui hasil dapatan soal selidik yang diberikan kepada responden berkaitan dengan efikasi kendiri dan motivasi terhadap pencapaian akademik pelajar perempuan jurusan STEM, mendapati min yang diperolehi daripada keseluruhan item yang telah dianalisis mempunyai nilai di tahap tinggi. Ini dapat dirumuskan bahawa keseluruhan item memberikan petunjuk yang baik kepada responden terhadap tahap efikasi kendiri dan tahap motivasi dalam menentukan pencapaian akademik pelajar.

Melalui hasil analisis kajian yang diperoleh juga menunjukkan bahawa terdapat hubungan di antara efikasi kendiri dan motivasi terhadap pencapaian akademik pelajar perempuan jursan STEM tetapi harus ditekankan bahawa hubungan yang diperolehi adalah hubungan yang sangat lemah. Walaupun begitu hubungan diantara efikasi kendiri dan motivasi menunjukkan bahawa terdapat hubungan diantara kedua pemboleh ubah utama yang telah dianalisis pada dapatan kajian. Di mana hubungan yang terdapat diantara efikasi kendiri dan motivasi yang diperoleh menunjukkan terdapat hubungan yang kuat di antara pemboleh ubah tersebut. Ini menunjukkan bahawa efikasi kendiri dan motivasi perlukan oleh responden untuk membantu mereka meneruskan pembelajaran dalam jurusan STEM.

Oleh itu, CGPA semester lepas yang merujuk kepada pencapaian akademik pelajar adalah secara keseluruhannya menujukkan keputusan yang memberansangkan, dimana majoriti responden 
memperoleh keputusan daripada taraf lulus sehingga ke taraf lulus dengan cemerlang. Usaha perlu dilaksanakan untuk mendorong pelajar perempuan STEM bahawa jurusan STEM ini merupakan pilihan utama pelajar serta didorong atas pilihan pelajar itu sendiri. Ini menunjukkan bahawa keduadua pemboleh ubah mampu memberikan kesan, walaupun keputusan yang diperolehi berdasarkan hubungan korelasi seperti yang telah dinyatakan terdapat hubungan sangat lemah, ia tetap mampu memberi persepsi bahawa pelajar perempuan jurusan STEM memerlukan efikasi kendiri dan motivasi untuk memperolehi pencapaian akademik yang cemerlang.

\section{Tahap efikasi kendiri pelajar perempuan jurusan STEM}

Keseluruhan hasil kajian menunjukkan tahap efikasi kendiri yang diperolehi oleh pelajar adalah tinggi. Ini merupakan dapatan yang positif terhadap tahap efikasi kendiri yang dimiliki oleh pelajar perempuan jurusan STEM.Berdasarkan hasil analisis terhadap item tahap efikasi kendiri pelajar perempuan jurusan STEM menunjukkan kesan yang positif di mana keseluruhan min skor adalah tinggi.

Hasil analisis terhadap item efikasi kendiri berkaitan dengan menumpukan perhatian adalah selari dengan kajian Cameron dan Jay (2017) yang menyatakan tahap efikasi kendiri pelajar adalah merujuk kepada penglibatan pelajar sewaktu pembelajaran dijalankan, ini juga mendorong individu dalam mengenal pasti peningkatan kepada pencapaian akademik pelajar. Elisabeth dan Lysann (2019) menyatakan efikasi kendiri yang diperolehi oleh pelajar perempuan jurusan STEM adalah disebabkan kemampuan pelajar tersendiri. Ini dapat dikaitkan dengan item efikasi kendiri yang mempunyai tahap min tinggi yang mana dapat juga dilihat bahawa pelajar perempuan jurusan STEM ini sentiasa mencuba berdasarkan kemampuan pelajar itu sendiri.

Oleh yang demikian, tahap efikasi kendiri yang dimiliki oleh pelajar adalah sangat penting terhadap pelajar perempuan jurusan STEM. Pencapaian akademik pelajar perempuan dalam jurusan STEM ini juga dipengaruhi oleh tahap efikasi kendiri pelajar kerana pelajar sendiri yang perlu berusaha dan mengawal selia keadaan dengan baik dalam mendapatkan keputusan yang baik. Efikasi kendiri itu juga mampu mengajar pelajar untuk berusaha dengan lebih baik dan tidak menjadikan pelajar mudah untuk berputus asa. Menurunnya efikasi kendiri pelajar akan membawa kepada perubahan dan penurunan terhadap subjek yang dipelajari dan sejurusnya memberikan kesan kepada pencapaian akademik pelajar di akhir semester. Ini kerana efikasi kendiri yang terdapat pada pelajar akan memberikan impak serta keputusan yang lebih cemerlang atau sebaliknya. Pada peringkat pengajian tinggi, kajian ini melihat bahawa tahap efikasi kendiri yang dimiliki oleh pelajar merupakan antara faktor yang menyumbang kepada kecemerlangan pencapaian akademik perempuan jurusan STEM.

\section{Tahap motivasi pelajar perempuanjurusan STEM}

Melihat kepada tahap motivasi pelajar perempuan jurusan STEM, nilai keseluruhan min skor berada pada tahap tinggi. Ini merupakan dapatan yang positif terhadap tahap motivasi yang dimiliki oleh pelajar perempuan jurusan STEM. Berdasarkan hasil analisis terhadap item motivasi pelajar perempuan jurusan STEM menunjukkan kesan yang positif di mana keseluruhan min skor yang diperoleh adalah tinggi.

Ini selari dengan Susana Rodríguez et al. (2019) menyatakan motivasi dipengaruhi oleh tingkah laku pelajar terhadap jurusan yang dipilih. Hasil kajian berkaitan dengan kenyataan tersebut adalah tentang item dapat melakukan tugas yang diberikan dalam kursus ini dengan cemerlang sama ada menyelesaikan masalah atau menjalankan tugas yang diberikan. Ini menunjukkan bahawa sikap pelajar mempengaruhi tahap motivasi yang dimiliki oleh pelajar. Hasil yang positif terhadap tingkah laku pelajar mempengaruhi tahap motivasi pelajar perempuan jurusan STEM ini juga disokong dengan item motivasi berkaitan pelajar menyalin nota bagi membantu mengingati bahan yang dipelajari. Ini boleh dikaitkan dengan hasil dapatan daripada Juan L Núñez dan Jaime León (2016) yang mengatakan motivasi pelajar akan lebih meningkat sekiranya pelajar faham akan tujuan tugasan dan aktiviti yang diberikan. 
Oleh yang berikut, tahap motivasi yang dimiliki oleh pelajar adalah diperlukan dalam memberikan impak yang positif terhadap pencapaian akademik pelajar perempuan jurusan STEM. Motivasi yang hadir dalam diri individu juga mampu memberikan kesan yang baik atau sebaliknya. Jadi ini dapat dilihat pada kajian ini bahawa terdapatnya motivasi dalaman dan luaran yang akan mempengaruhi pencapaian akademik pelajar yang terlibat. Meningkatnya motivasi yang dimiliki oleh pelajar akan membawa kepada dapatan positif terhadap pencapaian akademik pelajar. Begitu juga sebaliknya, menurunnya motivasi individu akan membawa kepada perubahan yang negatif yang akhirnya mempengaruhi keputusan yang bakal pelajar perolehi. Pada peringkat pengajian tinggi, kajian ini melihat bahawa tahap motivasi yang dimiliki oleh pelajar merupakan antara faktor yang menyumbang kepada kecemerlangan pencapaian akademik perempuan jurusan STEM.

\section{Hubungan di antara efikasi kendiri dan motivasi pelajar perempuan jurusan STEM dengan pencapaian akademik}

Hasil kajian terhadap hubungan di antara efikasi kendiri dan motivasi pelajar perempuan jurusan STEM di universiti awam dengan pencapaian akademik menunjukkan keputusan hubungan yang diperolehi adalah sangat lemah. Ini menunjukkan bahawa efikasi kendiri dan pemboleh ubah adalah antara faktor yang menyumbang kepada pencapaian akademik pelajar perempuan jurusan STEM. Perkaitan di antara efikasi dengan pencapaian akademik juga menujukkan hubungan yang diperoleh adalah hubungan sangat lemah, begitu juga dengan motivasi dan pencapaian akademik yang menunjukkan dapatan hubungan sangat lemah.

Efikasi kendiri dan motivasi juga merupakan faktor utama pelajar untuk memperoleh keputusan yang cemerlang di akhir setiap semester. Ini dapat dilihat berdasarkan tahap yang telah dianalisis pada efikasi kendiri dan juga motivasi terhadap pencapaian akademik pelajar perempuan jurusan STEM. Ianya boleh dirumuskan bahawa tahap efikasi kendiri adalah berkaitan dengan tahap motivasi pelajar yang terlibat. Begitu juga dapatan kajian Christian et al. (2018) hubungan antara motivasi dengan pencapaian akademik adalah dua konsep yang berkait rapat dengan motivasi pelajar. Ini kerana faktor motivasi merupakan faktor yang relevan dalam bidang akademik yang bakal mempengaruh efikasi kendiri pelajar sendiri.

Namun begitu dapatan kajian ini tidak menunjukkan hubungan yang signifikan di antara efikasi kendiri dan motivasi terhadap pencapaian akademik pelajar perempuan jurusan STEM. Melihat kepada dapatan yang berkaitan dengan efikasi kendiri, ini selari dengan kajian Allison et al. (2017) menunjukkan tidak terdapat hubungan yang signifikan di antara efikasi kendiri dengan pelajar perempuan. Jika dilihat pada motivasi kajian Hee dan Siti (2017) juga menunjukkan tidak terdapat hubungan yang signifikan antara tahap motivasi dengan pencapaiaan akademik. Walau bagaimanapun pada kajian, Wondu (2018) terdapat hubungan yang signifikan antara efikasi kendiri pelajar dengan motivasi pelajar yang mempengaruhi pencapaian akademik pelajar, ini adalah disebabkan terdapat pemboleh ubah berkaitan dengan tekanan dan kemurungan yang dilihat oleh pengkaji terhadap pencapaian akademik pelajar yang dikaji.

\section{Kesimpulan}

Oleh yang berikut, kajian ini mempunyai hubungan yang signifikan di antara efikasi kendiri dan motivasi terhadap pencapaian akademik pelajar perempuan jurusan STEM, tetapi harus ditekankan bahawa hubungan sangat lemah yang diperolehi daripada kajian ini mampu mempengaruhi pencapaian akademik yang cemerlang atau sebaliknya terhadap pelajar perempuan jurusan STEM. Secara keseluruhannya kajian ini dapat menyumbang kepada bidang pendidikan khususnya dalam jurusan STEM. Keseluruhan hasil kajian juga menujukkan bahawa pelajar perempuan jurusan STEM juga dilihat mampu memperoleh keputusan akademik yang cemerlang mengikut pada tahap efikasi kendiri dan tahap motivasi yang dimiliki. Beserta pada pengetahuan yang dimiliki tahap efikasi kendiri yang tinggi serta tahap motivasi yang tinggi mampu mengubah serta memastikan keputusan akademik yang diperolehi adalah cemerlang dan memuaskan berdasarkan usaha yang telah dibuat oleh pelajar perempuan jurusan STEM. Ini kerana keseluruhan perkaitan hasil kajian ini hanyalah ingin melihat 
kepada tiga aspek utama yang berkaitan dengan tahap efikasi kendiri dan tahap motivasi yang dimiliki oleh pelajar perempuan jurusan STEM terhadap pencapaian akademik pelajar.

Cadangan dapatan kajian yang boleh diberikan terhadap keseluruhan kajian ini adalah Kementerian Pengajian Tinggi perlu memberikan infrastruktur yang lengkap kepada pelajar jurusan STEM supaya pelajar lebih mempunyai motivasi yang tinggi untuk mempelajari jurusan mereka dengan lebih berkesan, ini juga akan mendorong kepada aspek pengajaran yang diberikan oleh pensyarah dan pembelajaran yang bersesuaian dengan masa kini. Selain itu, pensyarah yang terlibat dalam mengajar jurusan STEM harus memberikan peluang yang sama rata kepada pelajar perempuan terutamanya. Melalui ini, ia dapat memupuk semangat serta motivasi pelajar ke arah tahap yang lebih tinggi. Antara cadangan yang boleh diberikan kepada pengkaji akan datang adalah dicadangkan kepada pengkaji lain untuk melakukan penyelidikan dalam reka bentuk kualitatif dengan memilih responden berdasarkan keputusan CGPA yang diperolehi agar boleh dibandingkan setiap daripadanya berkaitan dengan efikasi kendiri dan motivasi, sama ada indikator tersebut memberikan kesan atau sebaliknya terhadap pencapaian akademik pelajar perempuan jurusan STEM.

Kesimpulannya, keseluruhan kajian ini diharapkan mampu memberikan sedikit penerangan beserta ilmu yang boleh digunakan serta menjadi bahan bacaan rujukan penyelidik-penyelidik yang berminat dalam bidang STEM pada masa akan datang. Oleh itu, diharapkan keseluruhan kajian ini mampu memberikan kesan yang baik terhadap bidang pengajian STEM, serta dunia akademik itu sendiri.

\section{Rujukan}

Amimah Mohammad Ayub. (2018). Kesedaran terhad mengenai pendidikan STEM di Malaysia. Prosiding Seminar Kebangsaan Majlis Dekan Pendidikan Universiti Awam:1093-1102. Terengganu : Penerbit Universiti Sultan Zainal Abidin.

Alexandra Garr-Schultz \& Wendi L. Gardner. (2018). Strategic self-presentation of women in STEM. Journal Social Sciences, 20(7), 1-16.

Allison Master, Sapna Cheryan, Adriana Moscatelli \& Andrew N. Meltzoff. (2017). Programming experience promotes higher STEM motivation among first-grade girls. Journal of Experimental Child Psychology, 160, 92-106.

Anne Deiglmayr, Elsbeth Stern \& Renate Schubert. (2019). Beliefs in "brilliance" and belonging uncertainty in male and female STEM students. Frontiers in Psychology, 10, 1-7.

Bandura, A. (1986). Social foundations of thought and action: A social cognitive theory. Englewood Cliffs, NJ: Prentice- Hall, Inc.

Cameron Sublett \& Jay Stratte Plasman. (2017). How does applied STEM coursework relate to mathematics and science self-efficacy among high school students? Evidence from a national sample. Journal of Career and Technical Education, 32(1),29-50.

Ching-Hsue Cheng, Yun-Chun Wang \& Wei-Xiang Liu. (2019). Exploring the related factors in students' academic achievement for the sustainable education of rural areas. Sustainability, 11,122.

Christian Schöber, Kerstin Schütte, Olaf Köller, Nele McElvany\& Miriam M. Gebauer. (2018).Reciprocal effects between self-efficacy and achievement in mathematics and reading. Science Direct, 63,1-11.

Elisabeth Höhne \& Lysann Zander. (2019). Sources of male and female students' belonging uncertainty in the computer sciences. Frontiers in Psychology, 10,1-13.

Hee Jee Mei \& Siti Liyana Mohamad Yusuff. (2011). Hubungan antara tahap motivasi dengan pencapaian akademik pelajar pendidikan jarak jauh Universiti Sains Malaysia. Journal of Science \& Mathematics Education, 1-11.

Juan L. Núñez \& Jaime León. (2016). The mediating effect of intrinsic motivation to learn on the relationship between student's autonomy support and vitality and deep learning. The Spanish Journal of Psychology, 19 (42), 1-8.

Kementerian Pendidikan Malaysia. (2013). Pelan pembangunan pendidikan Malaysia 2013-2025. Putrajaya: KementerianPendidikan Malaysia. 
Khuzaimah Mustapa \& Siti Salina Abdullah. (2019). Pengalaman kerjaya sebagai jururawat lelaki. Journal of Business and Social Development, 7(1), 1-8.

Krejcie \& Morgan. (1970). Menguasai penyelidikan dalam pendidikan :teori analisis \&interpretasi data. PTS Professional.

Kumar Jha C. \& Sarangi, S. (2018). Women and corruption: What positions must they hold to make a difference?. Journal of Economic \& Organisation, 151, 219-233.

Lizhi He, George Zhou, Geri Salinitri \& Lianrong Xu. (2020). Female underrepresentation in STEM subjects: an exploratory study of female high school student ts in China. Journal of Mathematics, Science and Technology Education, 16(1), 1-13.

Muhammad Abd Hadi Bunyamin. (2017). Membangunkan pendekatan bersepadu pendidikan STEM di Malaysia. 1-13.

Muhammad Dzharil Shah Andarin \& Noor Raudhiah Abu Bakar. (2017). Hubungan antara personaliti, gaya pembelajaran, faktor persekitaran dan keagamaan dengan pencapaian akademik dalam kalangan pelajar IPTS Selangor. Prosiding: 1-10. Kajang: Kolej Universiti Islam Antarabangsa Selangor.

Nur Amelia Adam \&Lilia Halim. (2019). Cabaran pengintegrasian pendidikan STEM dalam kurikulum Malaysia. Seminar Wacana Pendidikan 2019: (SWAPEN 2.0), Alor Setar, Kedah.

Pintrich, P. R., \& de Groot, E. V. 1990. Motivational and self-regulated learning components of classroom academic performance. Journal of Educational Psychology, 82(1),33-40.

Rebecca Lazarides \& Fani Lauermann. (2019). Gendered paths into STEM-related and languagerelated careers: girls' and boys' motivational beliefs and career plans in math and language arts. Frontiers in Psychology, 10,1-17.

Sabrina Solanki, Peter McPartlan, Di Xu\& Brian K. Sato. (2019). Success with EASE: Who benefits from a STEM learning community? PLOS ONE, 14(3), 1-20.

Sabrina Sobieraj \& Nicole C. Krämer. (2019). The Impacts of gender and subject on experience of competence and autonomy in STEM. Frontiers in Psychology, 10,1-16.

Sarah Banchefsky, Karyn L Lewis \& Tiffany A. Ito. (2019). The role of social and ability belonging in men's and women's pSTEM persistence. Frontiers in Psychology, 10,1-16.

Schwarzer, R., \& Jerusalem, M. 1995. Generalized self-efficacy scale. Windsor, UK: Nfer-Nelson.

Soleiman Ahmady, Nasrin Khajeali, Farshad Sharifi \& Zohre Sadat Mirmoghtadaei. (2019). Factor related to academic failure in preclinical medical education: A systematic review. Journal of Advances in Medical Education \& Professionalism, 7(2),74-85.

Susan Edgar, Sandra E. Carr, Joanne Connaughton \& Antonio Celenza. (2019). Student motivation to learn: is self-belief the key to transition and first year performance in an undergraduate health professions program?. BMC Medical Education, 19, 1-9.

Susana Rodríguez, José C. Núñez, Antonio Valle, Carlos Freire, María del Mar Ferradás \& Carolina Rodríguez-Llorente . (2019). Relationship between students' prior academic achievement and homework behavioral engagement: the mediating/moderating role of learning motivation. Frontiers in Psychology, 10, 1-10.

Wondu Teshome Beharu.(2018). Psychological factors affecting students academic performance among freshman psychology students in Dire Dawa University. Journal of Education and Practice, 9(4), 59-65.

Yasmeen Makarem \& Jia Wang. (2019). Career experiences of women in science, technology, engineering, and mathematics fields: A systematic literature review. Wiley Periodicals, 31,91111. 